\title{
Government expenditure and poverty reduction in the proliferation of new administrative areas of Central Kalimantan, Indonesia
}

\author{
Andrie Elia, Yulianto, Harin Tiawon, Sustiyah*, and Kusnida Indrajaya \\ University of Palangka Raya, Palangka Raya, Indonesia \\ *Correspondence email: sustiyah@agr.upr.ac.id
}

\section{ARTICLE INFO}

- Research Article

Article History

Received 13 June 2020

Accepted 28 July 2020

Published 31 October 2020

\section{Keywords}

government expenditure; GRDP; Kalimantan; labor absorption; poverty

\section{JEL Classification} H72; I38; J21

\begin{abstract}
The proliferation of new region in Indonesia is one of the most challenging issues related to regional autonomy, financial management and poverty reduction. The purpose of this study was to analyze the relationship between government expenditure and poverty linked to the regional economic activity and labor absorption. The study used a quantitative research by means of time series data collected from the new proliferation areas in Central Kalimantan, including Pulang Pisau, Katingan, East Barito, Seruyan, Gunung Mas, Murung Raya, Sukamara, and Lamandau. The analysis method used the path analysis to estimate statistical parameters indicating relationship between variables. The research result shows that poverty significantly affects on government expenditure in the new eight regency in Central Kalimantan province. Poverty has also had an impact on government expenditure through the provision of employment and Gross Regional Domestic Product (GRDP). The local government is expected to manage more effectively regional finances that focus on community economic activities. The policy also opens investment opportunity to increase economic activity and create jobs based on the prominent regional product such as agriculture, plantation and mining sectors. Investment can increase employment and indirectly reduce poverty.
\end{abstract}

Citation: Elia, A., Yulianto, Tiawon, H., Sustiyah, \& Indrajaya, K. (2020). Government expenditure and poverty reduction in the proliferation of new administrative areas of Central Kalimantan, Indonesia. Journal of Socioeconomics and Development, 3(2), 145-155. https://doi.org/10.31328/jsed.v3i2.1410

ISSN 2615-6075 online; ISSN 2615-6946 print (C)WG Press, 2020

\section{INTRODUCTION}

Regional autonomy as a form of implementation of the principle of decentralization in government administration has been running since early 2000 . This policy is to respond to the mandates of the community needs and is a conceptualization of the division of power theory concepts that divide the power of the state vertically. In this context, power is shared between the central government on the one hand and the regional government on the other, which is legally constitutional within the framework of the Unitary Republic of Indonesia. This condition has implications for changes in the development paradigm that prioritizes various public policies in government services, the dynamics and processes of democratization, community empowerment, and regional economic independence. This policy is seen as a new way to create a better direction in the governance scheme in all fields.

Since regional autonomy was implemented, the mechanism of governance has been complemented 
with broad, real, and proportionately responsible authorities. Local government authority is strengthened with regulations, transfer mechanisms, and fair use of resources as well as a transparent, effective, and efficient financial balance between the central and regional governments. Regional government financing to balance central and regional government finances is carried out on the basis of decentralization, deconcentration, and assistance tasks. Development carried out in the region refers to the allocation of the budget to carry out programs and activities in many sectors. In addition, local governments are required to explore other funding sources by optimizing the role and potential of the local economy.

One important factor influencing the success of decentralization is the use of sufficient financial, human, and physical resources to support the implementation of functions assigned to the regions. The problem of decentralization is not just an adequate amount of funds, but the extent to which regional authorities can determine the use of financial resources in the region.

According to Liu, Martinez-Vazquez, \& Wu (2017), fiscal decentralization provides a significant advantage to the efficiency of public spending. Large potential losses can lead to increased regional inequality. Fiscal decentralization at the district level in China leads to greater inequality with provinces. Quantitative fiscal decentralization tends to have a greater influence on regional inequality in terms of expenditure. The fact is that decentralized spending is a much more significant indicator of decentralization. This is supported by the opinion of Qiao, Martinez-Vazquez, \& Xu (2008) that experiences in China by developing theoretical models of fiscal decentralization where overall national economic growth and equity in the distribution of regional fiscal resources are two objectives pursued by the central government. This model was tested using panel data for 1985-1998, showing that fiscal decentralization in China has led to significant economic growth and regional inequality.

Fiscal decentralization has raised the attention of governments, academic studies, and international institutions intending to increase economic growth in recent years. Fiscal decentralization that has been developed takes into account fiscal autonomy and the fiscal interests of local governments. Regional and hierarchical fiscal imbalances are closely related to national, provincial, and local levels of government which are illustrated by new countries such as local Vietnam (Hong Vo, Nguyen, Ha, \& Tran, 2019).

According to Siburian (2019), fiscal decentralization reduces regional income inequality. Fiscal decentralization reduces the regional income gap more significantly than the centralized system. The decentralization system gives regional governments autonomy in designing development programs that are in line with the unique characteristics of a particular region and distributing resources more equitably. Decentralization is needed by local governments to provide public services efficiently. Meanwhile, according to Salqaura, Mulyo, \& Darwanto (2019), fiscal decentralization policy provides an opportunity for the provincial government to regulate the allocation of government spending. Total expenditure significantly contributes to the Gross Regional Domestic Product (GRDP) of the agricultural sub-subsector. Foreign investment has a significant positive effect on animal husbandry, and domestic investment has a negative one on the GRDP's food crops subsector. The provincial government needs to support the agricultural subsector by allocating expenditures that will increase the GRDP of the agricultural subsector and increase foreign direct investment and domestic investment into the agricultural subsector.

According to Canare, Francisco, \& Caliso (2020), decentralization has become a public finance reform that is common among developing countries in the last few decades. Some advocates are pushing for decentralization reforms in response to the problem of increasing income inequality. With decentralization, local governments have better information about the needs and preferences of the residents. Meanwhile, the central government has better economies of scale in providing public services and usually has good access to more important resources.

López-Bazo, Monastiriotis, \& Ramos (2014) argued over how the impact of open trade on regional disparities within the country, how regional disparities affect the quality of government at the national level, and how the effects of various forms of decentralization on income inequality at the household level. This contributes to a better understanding of the complex relationship between inequality and economic growth to stimulate future 
research on this topic. Soejoto, Fitrayati, Rachmawati, \& Sholikhah (2016) argued that the development of regional development includes four indicators namely economic growth, fiscal decentralization, income inequality, and educational inequality. These indicators well describe the real conditions of public welfare. Fiscal decentralization between the central and regional governments is measured by the transfer of balanced funds. Balance funds come from taxes and natural resources fund sharing, general allocation funds, and special allocation funds. Thus, decentralization will pay more attention to fiscal decentralization, income inequality, and educational inequality. This becomes an important indicator of the success of economic development, not just looking at economic growth in general.

According to Syari, Syamsurijal, \& Robiani (2017), simultaneous fiscal decentralization has a significant effect on district/city GRDP in South Sumatra. However, in a partial test, the ratio of district/city to provincial expenditure is positive and not significant. This relates to the allocation of spending that has not had a direct impact on the economy of the district so that it has not yet given results that can support economic growth. GRDP is the total value added of goods and services produced from all economic activities in all regions in a certain year period. GRDP is useful to show the ability of economic resources produced by a region. If a region has a large GRDP figure, it means that economic resources are also abundant.

Development expenditure (capital expenditure) is used for investment and implementing predetermined government programs. Government development spending is expected to grow continuously to accelerate the national economy, strengthen finances, and improve the welfare of the community. The amount of regional expenditure continues to increase in recent years, reflecting regional government policies and the direction of regional development.

The provincial government of Central Kalimantan supplies regional spending for strengthening regional development, stimulating regional economic growth, and reducing poverty levels. Analysis of regional expenditures needs to be carried out as a basis for the evaluation and correction of the implementation of development policies in Central Kalimantan. Government spending affects regional economic growth and reduces poverty levels in society. Economic growth in the province of Central Kalimantan in the last ten years has been above six percent (BPS of Central Kalimantan, 2020a). In the same period, the number of poor people also decreased from being $6.77 \%$ to $4.81 \%$ (BPS of Central Kalimantan, 2020b). To overcome poverty, there are several important factors including GRDP, labor absorption, and government spending. Government expenditure can also accelerate economic growth which in turn will increase the income of the population under the poverty line and at the same time reduce poverty levels.

Three sectors support the economic growth of Central Kalimantan namely (a) the agriculture, livestock, forestry, and fisheries sector, (b) the mining and quarrying sector, and (c) the processing industry sector. In recent years, three sectors have increased and played a significant role in the formation of GRDP. Local government plays an important role in synergizing the three sectors to support the success of regional development and economic growth. These sectors are also able to absorb a significant number of workers.

The primary sector allocation has become a consideration for the central government in supporting the proliferation of new eight administrative areas in Central Kalimantan Province based on Law No. 5 in 2020. The new areas are Pulang Pisau, Katingan, East Barito, Seruyan, Gunung Mas, Murung Raya, Sukamara, and Lamandau. Forestry is the most dominant sector in the new areas, bringing about forests product such as wood and rattan. Moreover, the agricultural sector displays an important commodity of oil palm, rubber, coffee, and cocoa. Meanwhile, the mining and quarrying sectors rely on coal and gold mining. The manufacturing sector is also commonly found in the proliferation areas. This industrial sector is formed from the processing of forest, agriculture, plantation, and fishery products, namely the palm oil industry, rattan processing industry, furniture, the food industry, and processed fishery products. On the contrary, coal, gold, palm oil, rubber, and cocoa become a prominent commodity of exports for new regions. These sectors are expected to drive economic activities and development of the proliferation areas rapidly.

Furthermore, the primary sector generally employs a very large number of workers and will 
certainly affect economic growth, increase productivity, and produce a high output. This will also immediately increase income and purchasing power so that the economic growth of a region will develop (Mankiw, 2019).

The study is aimed to analyze the relationship between government expenditure and poverty, and also concerning the regional economic activity and labor absorption in the new proliferation area in Central Kalimantan.

\section{RESEARCH METHOD}

The research approach is quantitative research using secondary data. This research is confirmatory in which the researcher has determined several factors that influence government expenditure in eight regencies of Central Kalimantan Province. The new regencies are Pulang Pisau, Katingan, East Barito, Seruyan, Gunung Mas, Murung Raya, Sukamara, and Lamandau.

The variables in this study consisted of GRDP, labor absorption, poverty, and government expenditures from 2006 to 2018 in the new regency of Central Kalimantan Province. The operational definition of variables are as follows.

a. Regional government expenditure is the realization of total regional expenditure in the form of capital expenditure in the new regency of Central Kalimantan Province which is expressed as a percentage of provincial government expenditure.

b. GRDP is the overall value added of goods and services by various economic sectors in the new regency of Central Kalimantan Province, expressed as a percentage of provincial GRDP.

c. Labor Absorption is the number of working age population (aged 15 years and over) who work in the new regency of Central Kalimantan Province, expressed as a percentage of the provincial labor force.

d. Poverty is measured by the percentage of poor people in the new regency of Central Kalimantan Province.

Figure 1 explains the relationship among observed variables expressed through equations comprising the direct and indirect paths. The direct path includes the relationship between GRDP, poverty, and labor absorption separately to government expenditure. The indirect path is displayed through the effect of poverty on the government expenditure using GRDP and labor absorption as mediators.

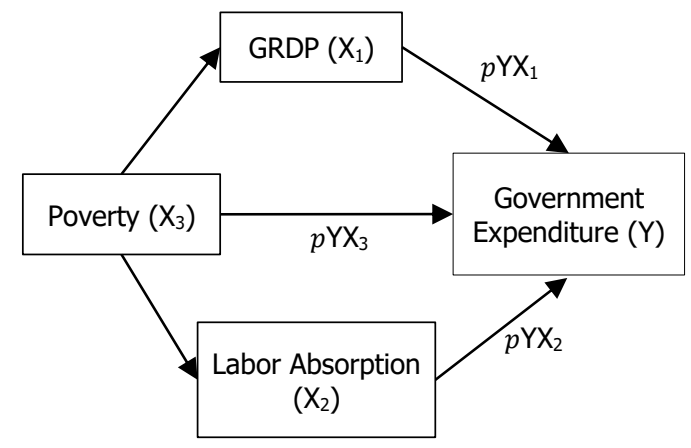

Figure 1. Path analysis model

Based on the path analysis above, obtained three equation models as follows:

$$
\begin{aligned}
& \mathrm{Y} 1=\mathrm{pYX} 3+\varepsilon \\
& \mathrm{Y} 2=\mathrm{pYX} 1+\mathrm{pYX} 3+\varepsilon \\
& \mathrm{Y} 3=\mathrm{pYX} 2+\mathrm{pYX} 3+\varepsilon
\end{aligned}
$$

in which $\mathrm{X} 1$ is GRDP, and $\mathrm{X} 2$ is labor absorption, $\mathrm{X} 3$ is poverty, $Y$ is government expenditures, $p$ is path coefficient, and $\varepsilon$ is an error.

The analytical method uses path analysis, with the Statistical Package for the Social Sciences (SPSS) software application. The path analysis of relationship construction is presented in Figure 1. Evaluation of the model in each path conducted using the $t$-test on each parameter of the equation.

\section{RESULT AND DISCUSSION}

\section{Description of New District}

Central Kalimantan Province initially has 6 regencies/cities that are Palangka Raya City, Kapuas Regency, East Kotawaringin Regency, West Kotawaringin Regency, South Barito Regency, and North Barito Regency. Based on various considerations, especially responding to the aspirations of the community for the effectiveness of development implementation at the local level. In 2002, the central government approved the proliferation of a new administrative area. The new eight regencies are Sukamara, Lamandau, Seruyan, Katingan, Pulang Pisau, Gunung Mas, East Barito, and Murung Raya. As a result, there are eight new regencies added to become 14 regencies (Figure 2 ). 
The new administrative areas proliferated from the administrative areas as follows. Sukamara Regency is a formation of new administrative areas of West Kotawaringin Regency. Lamandau Regency is proliferated from West Kotawaringin Regency. Seruyan Regency is expanded East Katowaringin Regency. Katingan Regency is proliferated from Palangka Raya City and Kotawaringin Timur Regency.
Pulang Pisau Regency is shaped from Palangka Raya City and Kapuas Regency. Gunung Mas Regency is developed from Palangka Raya City and Kapuas Regency. East Barito Regency is developed from South Barito Regency and North Barito Regency. Murung Raya Regency is developed from North Barito Regency. The percentage of GRDP in eight new regencies are presented in Table 1.

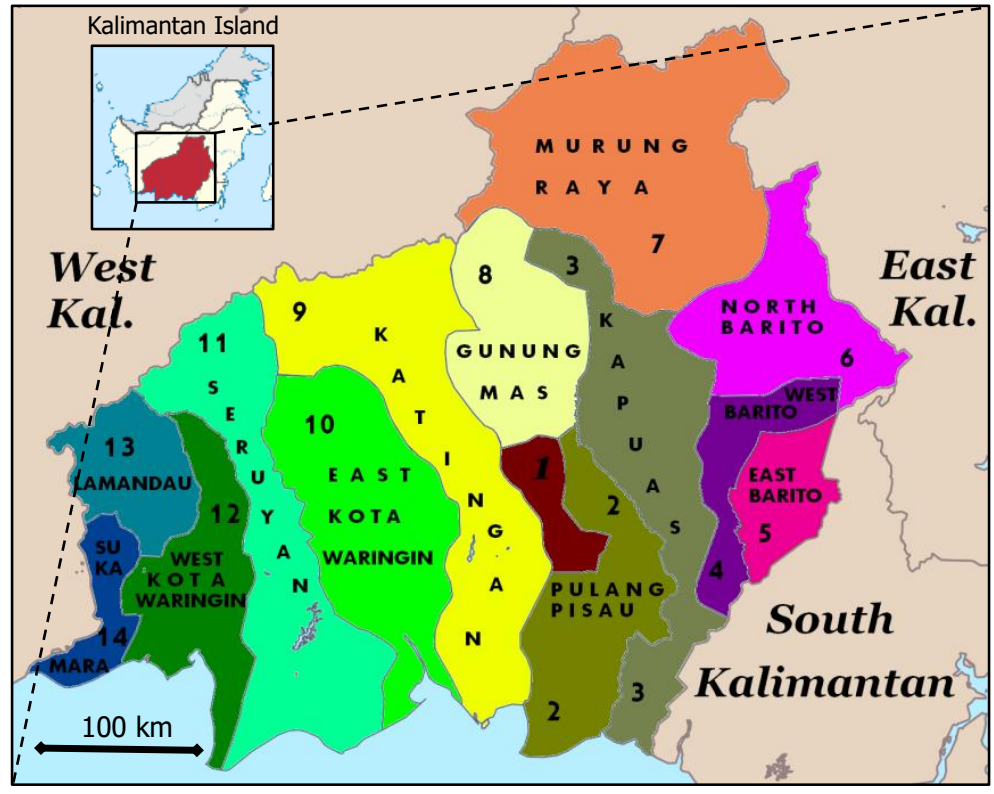

Figure 2. Map of the regency area in Central Kalimantan

Table 1 shows the pattern of Gross Regional Domestic Product (GRDP) distribution in eight new regencies. The largest percentage of GRDP during 2010-2018 in the Seruyan Regency with a value ranging from $5.82 \%$ to $6.74 \%$ and an average percentage of $6.33 \%$. The lowest percentage of Sukamara Regency with the magnitude range from $2.80 \%$ to $2.95 \%$ and an average percentage of $2.88 \%$. This shows that Seruyan Regency has more economic resources than other regencies. Meanwhile, Sukamara Regency has low economic resources. GRDP has a role as one of the main indicators in the economy. This economic indicator can be used to see the economic growth rate of a region. This GRDP is useful to show the ability of economic resources produced by a region.

Table 2 shows that the pattern of poverty in the eight new regencies during 2003-2018. The largest percentage of poverty found in the East Barito Regency with an average percentage range from
$6.56 \%$ to $13.47 \%$ and an average percentage of $10.10 \%$. The lowest percentage of Lamandau Regency ranged from $3.15 \%$ to $9.59 \%$ and an average percentage of $6.16 \%$. This illustrates that the people in East Barito Regency have low welfare, while the people in Lamandau Regency are more prosperous than other regencies.

Table 3 shows the pattern of labor absorption in the eight new regencies. The highest labor absorption in the East Barito Regency with a percentage in 2011-2018 between $72.52 \%$ and $81.33 \%$ and an average percentage of $77.05 \%$. The lowest percentage is in Murung Raya Regency in the range of $65.09 \%$ to $73.96 \%$ and an average of $64.45 \%$. The higher the labor absorption shows that the area has high economic activities that devote a lot of labor absorption. As such, North Barito District has high employment opportunities compared to other regencies. 
Table 1. GRDP in Eight New Districts in Central Kalimantan Province

\begin{tabular}{|c|c|c|c|c|c|c|c|c|c|c|}
\hline New regency & 2010 & 2011 & 2012 & 2013 & 2014 & 2015 & 2016 & 2017 & 2018 & 2019 \\
\hline & \multicolumn{10}{|c|}{......... \% } \\
\hline Lamandau & 3.67 & 3.64 & 3.75 & 3.73 & 3.73 & 3.66 & 3.65 & 3.61 & 3.61 & 3.65 \\
\hline Katingan & 5.19 & 5.15 & 5.26 & 5.30 & 5.41 & 5.48 & 5.49 & 5.43 & 5.43 & 5.47 \\
\hline Pulang Pisau & 3.42 & 3.34 & 3.40 & 3.46 & 3.58 & 3.65 & 3.61 & 3.54 & 3.53 & 3.52 \\
\hline Gunung Mas & 3.44 & 3.48 & 3.56 & 3.67 & 3.75 & 3.78 & 3.79 & 3.75 & 3.73 & 3.82 \\
\hline Murung Raya & 5.98 & 6.20 & 6.12 & 5.97 & 5.73 & 5.58 & 5.51 & 5.45 & 5.55 & 5.50 \\
\hline
\end{tabular}

Source: (BPS of Central Kalimantan, 2020a)

Table 2. Poor People in Eight New Districts in Central Kalimantan Province

\begin{tabular}{|c|c|c|c|c|c|c|c|c|c|c|c|c|c|}
\hline New regency & 2003 & 2005 & 2007 & 2009 & 2011 & 2012 & 2013 & 2014 & 2015 & 2016 & 2017 & 2018 & 2019 \\
\hline & & & & & & & \multicolumn{7}{|l|}{$\% \quad \ldots$} \\
\hline Sukamara & 10.69 & 10.50 & 9.00 & 5.91 & 5.90 & 5.36 & 4.56 & 4.29 & 4.32 & 3.73 & 3.36 & 3.19 & 3.16 \\
\hline Lamandau & 9.59 & 9.60 & 7.76 & 5.57 & 5.18 & 4.66 & 4.87 & 4.66 & 3.95 & 3.80 & 3.52 & 3.15 & 3.01 \\
\hline Katingan & 12.67 & 11.90 & 8.68 & 7.00 & 6.47 & 6.10 & 6.55 & 6.42 & 6.53 & 6.23 & 5.78 & 5.22 & 5.02 \\
\hline Pulang Pisau & 11.99 & 10.40 & 9.18 & 6.23 & 5.45 & 5.24 & 5.45 & 5.35 & 5.65 & 5.49 & 5.19 & 4.51 & 4.24 \\
\hline Murung Raya & 11.00 & 10.20 & 8.91 & 6.94 & 6.30 & 5.78 & 6.44 & 6.24 & 6.57 & 6.32 & 5.88 & 6.28 & 6.00 \\
\hline
\end{tabular}

Source: (BPS of Central Kalimantan, 2020b)

Table 3. Labor Absorption in Eight New Districts in Central Kalimantan Province

\begin{tabular}{|c|c|c|c|c|c|c|c|c|}
\hline New regency & 2011 & 2012 & 2013 & 2014 & 2015 & 2017 & 2018 & 2019 \\
\hline & \multicolumn{8}{|c|}{.......... \% } \\
\hline Sukamara & 73.49 & 72.49 & 74.46 & 75.53 & 71.60 & 73.61 & 74.18 & 73.37 \\
\hline Lamandau & 75.19 & 77.56 & 71.90 & 65.55 & 71.76 & 73.00 & 67.93 & 68.65 \\
\hline Seruyan & 74.41 & 65.60 & 68.75 & 68.37 & 74.23 & 72.86 & 74.90 & 71.66 \\
\hline Katingan & 73.36 & 71.61 & 69.04 & 70.83 & 72.20 & 65.97 & 69.49 & 70.79 \\
\hline Pulang Pisau & 73.36 & 69.51 & 66.93 & 67.34 & 74.48 & 74.72 & 70.98 & 75.31 \\
\hline Gunung Mas & 73.44 & 79.05 & 76.94 & 72.24 & 77.44 & 74.87 & 75.76 & 73.78 \\
\hline Barito Timur & 74.35 & 81.33 & 77.52 & 72.52 & 80.43 & 74.11 & 79.09 & 74.89 \\
\hline Murung Raya & 73.96 & 70.91 & 69.69 & 65.09 & 71.73 & 68.83 & 69.58 & 66.49 \\
\hline
\end{tabular}

Source: (BPS of Central Kalimantan, 2020c)

\section{The Effect of Poverty on Government Expenditures}

The effect of poverty on government expenditure in the new regency, Central Kalimantan Province presented in Table 4. The result shows that poverty has a significant effect on government expenditure in the new regency, Central Kalimantan Province. This is indicated from the F-statistic value of 0.000 which is smaller than alpha 0.05 . The coefficient of determination is 0.211 , which means that the diversity of data that can be explained by the model is $21.1 \%$, the poverty variable influences government expenditure, the remaining $78.9 \%$ is influenced by other variables not yet included in the model.

The regression coefficient on the poverty variable ( $\rho$ ) is 0.204 with positive parameters. This shows that every time there is an increase in poverty by $1 \%$. It will have an impact on increasing government expenditure in eight new regencies, Central Kalimantan Province by $20.4 \%$. The t-statistic value is 4.564 with $p$-value of 0.000 ( $p$-value< $<0.05$ ). It means that poverty has a significant effect on government expenditure.

Table 4. The Estimated Government Expenditure by Poverty

\begin{tabular}{lccc}
\hline Variable & $\rho$ & $\mathrm{t}$ & $\mathrm{p}$-value \\
\hline Constanta & 4.684 & & 0.000 \\
X3 (Poverty) & 0.204 & 4.566 & 0.001 \\
\hline
\end{tabular}

Government expenditure is expenditure carried out in the context of purchasing/procurement or construction of tangible fixed assets that have a 
value of more than twelve months for use in government activities. This study notes that poverty has a significant effect on government expenditure in the new regency, Central Kalimantan Province.

Government expenditure can have a significant impact on economic growth. Economic growth is a necessary condition for poverty reduction. The growth should spread to each income group, including the poor population group (Sukirno, 2002). Potential costs of inequality in fiscal decentralization as a development strategy. At the same time, it is important to stress the importance of implementing a fiscal equalization program to ensure the overall success of decentralization policies. Fiscal equity efforts that can be carried out by provincial governments tend to reduce the adverse effects of fiscal decentralization on intra-provincial inequality (Liu et al., 2017). According to Asmara \& Suci (2019), fiscal decentralization aims to increase regional financial independence and to reduce financial dependence on the central government, but in practice, there are still many regions that depend on central funding for regional development. Regional financial independence has a significant positive effect on economic growth, while the Balancing Fund ratio has a significant negative effect on economic growth.

\section{The Effect of Poverty through GRDP on Government Expenditure}

The effect of poverty through GRDP on government expenditure in the new regency, Central Kalimantan Province is presented in Table 5. The table indicates a significant effect of the poverty variable through GRDP on government expenditure. This is indicated from the F-statistic with the $p$-value is smaller than alpha 0.05 . The coefficient of determination is 0.364 which means that the diversity of data explained by the model is $36.4 \%$ of the poverty variable through GRDP affecting the government expenditure, the remaining $63.6 \%$ is influenced by other variables not yet included in the model.

Table 5 shows that the poverty and GRDP variables simultaneously affect government expenditure. The regression coefficient on the poverty variable through GRDP $(\rho)$ is -0.210 with a negative coefficient and coefficient of 0.572 the GRDP variable. This means that if there is an increase in poverty and GRDP by $1 \%$, it will have an impact on decreasing government expenditure in the eight new regencies of Central Kalimantan Province with $p$-value of 0.001 . This means that poverty through GRDP has a significant effect on decreasing government expenditure.

Table 5. The Estimated Government Expenditure by Poverty Through GRDP

\begin{tabular}{lccc}
\hline Variable & $\mathrm{P}$ & $\mathrm{t}$ & $\mathrm{p}$-value \\
\hline Constanta & 2.053 & & 0.000 \\
X1 (GRDP) & 0.572 & 6.304 & 0.000 \\
X3 (Poverty) & -0.210 & -1.025 & 0.001 \\
\hline $\mathrm{R}^{2}=0.364$ & & &
\end{tabular}

The economic growth shows the extent to which economic activity will generate additional community income in a given period. In other words, the economy is said to have experienced growth if the real income of the people in a particular year is greater than do so the previous year. Poverty is a classic problem that is still being faced by any region or country. Many countries have not been able to fully overcome poverty, especially developing countries like Indonesia. The results of the study note that poverty through the GRDP has a significant effect on government expenditure in the new regency, Central Kalimantan Province.

Nyoman, Sudewi, \& Wirathi (2013) argued that the implementation of fiscal decentralization policies has a positive impact on the development of the potential and creativity of local governments. Effectiveness in managing the results of regional wealth affects regional revenue which can then be used to improve the welfare of the community. Fiscal decentralization and economic growth simultaneously have a significant effect on poverty. Thus, fiscal decentralization and economic growth significantly have reduced the number of poor people.

According to Salqaura et al. (2019), one of the government's interventions to encourage increased agricultural sector output is through fiscal policy in the form of government spending. The government expenditure used is the total provincial government expenditure in the aggregate. The existence of a fiscal decentralization policy provides an opportunity for the provincial government to regulate the allocation of government spending. The provincial government needs to support the agricultural subsector by allocating expenditures that will increase the GRDP of the agricultural subsector and 
increase foreign direct investment and domestic investment into the agricultural subsector.

Suwardi (2011) argued that local government expenditure in the infrastructure and education sectors significantly influences agricultural productivity and poverty. The study also found that the effect of local government expenditure on poverty was highest shown by road infrastructure, followed by literacy and irrigation rates.

\section{Effect of Poverty Rate through Labor Absorption on Government Expenditure}

The effect of poverty through labor absorption on government expenditure are presented in Table 6 . The table shows a significant effect of the poverty variable through labor absorption on government expenditure. This is indicated by the F-statistic with $\mathrm{p}$-value is smaller than 0.05 . The coefficient of determination is 0.281 which means that the variety of data that can be explained by the model is $28.1 \%$ of the poverty variable through labor absorption affects government expenditure, the remaining $71.9 \%$ is influenced by other variables not yet included in the model.

Table 6. The Estimated Government Expenditure by Poverty Through Labor Absorption

\begin{tabular}{lccc}
\hline Variable & $\rho$ & $\mathrm{t}$ & $\mathrm{p}$-value \\
\hline Constanta & 14.962 & & 0.000 \\
X2 (Labor Absorption) & -1.003 & -3.980 & 0.002 \\
X3 (Poverty) & -0.371 & -2.942 & 0.015 \\
\hline $\mathrm{R}^{2}=0.281$ & & &
\end{tabular}

Table 6 shows that the variables of poverty and labor absorption simultaneously affect government expenditure. The regression coefficient on the poverty and labor absorption variables are -0.371 and -1.003 , respectively. It means that an increase of $1 \%$ in poverty and labor absorption variables will have an impact on decreasing government expenditure in the eight new regencies of Central Kalimantan Province. This means that poverty through labor absorption has a significant effect on decreasing government expenditure. In other words, an increase in government spending will be able to affect the decrease in the number of poor people through efforts to expand job opportunities.

The labor force is human capital that drives economic activities that produce goods/services in the regions. Poverty is a condition in which a person or group of people is unable to fulfill their basic rights to maintain and develop a dignified life. Poverty is also seen as the inability of the economy to meet basic food and non-food needs (measured in terms of expenditure). The growth of the workforce is traditionally regarded as one of the positive factors that spur economic growth. The greater number of workers means that it will increase the level of production, while greater population growth means the size of the domestic market is greater (Todaro \& Smith, 2015). Based on the results, the study notes that the level of poverty through employment has a significant effect on government expenditure in the new regency, Central Kalimantan Province.

According to Fahd \& Rasyid (2017), regional autonomy provides a more flexible regional government management in implementing its development strategy, especially in terms of allocating regional spending. The allocation of capital expenditures affects the level of poverty but does not directly affect the unemployment rate.

\section{Research Implication}

The results of this study provide an overview of the relationship between government expenditure, GRDP, labor absorption, and poverty rates in new proliferation areas in Central Kalimantan. This study provides the implications as follows.

First, poverty shows a significant effect on government spending. This is certainly inseparable from the government's process in developing the regional economy, so that the government is expected to be more effective and efficient in managing regional finances that provide benefits to the economy of the community such as the provision of economic infrastructure. Government policy is to ensure the availability of strategic staples and reduce the community problem and empower the poor. Strategies that can be carried out by the government include increasing the competitiveness of regional superior products, developing the creative economy in the entrepreneurial community, and developing household businesses. It is expected to encourage the economy's creativity and increase added value to regional production in Central Kalimantan. According to Ferraro \& Simorangkir (2020), poverty alleviation programs need to be oriented towards environmental protection to prevent deforestation. Local governments need to understand that the poor are generally very dependent on natural resources and 
on deforestation as a means of obtaining consumer goods and providing livelihood security.

Second, an increase in labor absorption effects reducing the poverty rate. The government in the expanded region needs to carry out promotion and investment cooperation, as well as to facilitate investment for the public and the private sector. This will open up employment in various sectors and can increase the absorption of regional labor in the new regency, Central Kalimantan Province. At the same time, local governments also need to pay attention to food crop farming for the sustainability of local people' lives that fulfill environmental conservation aspects (Wardie \& Sintha, 2018). Agricultural life of local people who meet conservation principles adjacent to forests, which hold a harmonious relationship of forest and land, by managing land in a limited area (1-2 ha) without the risk of land fires (Nopembereni, Sugiyanto, Sukesi, \& Yuliati, 2019). According to Bappenas (2008), the economic performance of new autonomous regions is lagging behind in comparison to parent regions and other regions, generally due to limited human resources, and inadequate government support for the economy through public investment.

Third, poverty has been successfully reduced in the last few years. The government needs to make efforts to perform more optimally to create more jobs and improve the economy so that poverty can be further suppressed. Government policies are directed at increasing the application of agricultural technology, increasing production in the plantation, fishery, and forestry sectors. The plantation sector is dominated by oil palm, rubber, coffee, and cocoa plantation companies. The mining and quarrying sector that has priority is coal and gold mining. The manufacturing sector is more focused on the processing of forest products, agriculture, and plantations, namely the palm oil industry, the rattan processing industry, furniture, the food industry from agricultural products and processed fishery products. In the short term, regional proliferation encourages changes in personnel performance and development spending needed to stimulate demand for goods and services produced by the local area. Local governments generally fully support efforts to develop agriculture or the primary sector as the economic basis for the new autonomous regions. This results in a more even distribution of the new autonomous economic potentials that are equal to the parent regions (Bappenas, 2008).

\section{CONCLUSION AND SUGGESTION}

Poverty shows a significant effect on government spending in the eight new regencies in Central Kalimantan Province. These findings indicate that the government is expected to be more effective and efficient in managing regional finances that focus on community economic activities, such as economic infrastructure development. The regional proliferation policy also opens opportunities and is more flexible for local governments in managing development strategies through the allocation of regional spending.

Poverty also has an impact on government spending through the provision of employment and GRDP. These findings indicate that increasing economic activity can provide employment and welfare so that poverty can be further reduced.

The new proliferation areas are enhanced to aggressively promote investment to increase economic activity and create jobs. This work is expected to increase community income and reduce poverty in the regions. The government can allocate government spending to stimulate an increase in the GDRP and open up investment opportunities for the public and the private sector in the agriculture, plantation, and mining sectors. Furthermore, the investment can increase employment and indirectly reduce poverty.

\section{ACKNOWLEDGMENT}

Appreciation to the government of the province of Central Kalimantan, especially in the eight new proliferation areas that have facilitated this research activity.

\section{REFERENCES}

Asmara, A., \& Suci, S. C. (2019). Pengaruh kemandirian keuangan daerah terhadap tingkat kemiskinan di Provinsi Banten. Jurnal Manajemen Pembangunan Daerah, 6(1), 41-53. https://doi.org/10.29244/jurnal_mpd.v6i1.24645

Bappenas. (2008). Evaluation of The Proliferation of Administrative Region in Indonesia, 2001-2007. Jakarta: BRIDGE, Bappenas-UNDP. Retrieved from 
https://www.undp.org/content/dam/indonesia/do cs/pemekaran_EN.pdf

BPS of Central Kalimantan. 2020a. Regency/City GRDP Growth 2011-2019. BPS of Central Kalimantan. Palangka Raya. Retrieved from https://kalteng.bps.go.id/dynamictable/2017/03/0 8/192/-laju-pertumbuhan-pdrb-provinsikalimantan-tengah-atas-dasar-harga-konstanmenurut-lapangan-usaha-2011-2019-persen-.html

BPS of Central Kalimantan. 2020b. Dinamics of Poverty. BPS of Central Kalimantan. Palangka Raya. Retrieved from https://kalteng.bps.go.id/dynamictable/2020/07/1 0/568/perkembangan-kemiskinan-di-kalimantantengah-1999-2019.html

BPS of Central Kalimantan. 2020c. National Labor Force Survey Result. BPS of Central Kalimantan. Palangka Raya. Retrieved from https://kalteng.bps.go.id/dynamictable/2019/02/0 7/284/tingkat-partisipasi-angkatan-kerjamenurut-kabupaten-kota-di-provinsi-kalimantantengah-2011-2015-dan-2017-2019.html

Canare, T., Francisco, J. P., \& Caliso, R. A. C. (2020). Decentralization and income inequality in a panel and cross-section of countries. Journal of International Development, 32(4), 543-579. https://doi.org/10.1002/jid.3468

Fahd, Y., \& Rasyid, S. (2017). The effect of regional financial performance on capital expenditure allocation and its implications on poverty and unemployment rate. Jurnal Analisis, 6(2), 194$201 . \quad$ Retrieved from http://pasca.unhas.ac.id/jurnal/files/58db97fba10 cd4f47bfa6492eed1fa77.pdf

Ferraro, P. J., \& Simorangkir, R. (2020). Conditional cash transfers to alleviate poverty also reduced deforestation in Indonesia. Science Advances, 6(24), https://doi.org/10.1126/sciadv.aaz1298

Hong Vo, D., Nguyen, T., Ha, D. T. T., \& Tran, N. P. (2019). The disparity of revenue and expenditure among subnational governments in Vietnam. Emerging Markets Finance and Trade. 1-12. https://doi.org/10.1080/1540496X.2019.1605896

Liu, Y., Martinez-Vazquez, J., \& Wu, A. M. (2017). Fiscal decentralization, equalization, and intraprovincial inequality in China. International Tax and Public Finance, 24(2), 248-281. https://doi.org/10.1007/s10797-016-9416-1

López-Bazo, E., Monastiriotis, V., \& Ramos, R. (2014). Spatial inequalities and economic growth.
Spatial Economic Analysis, 9(2), 113-119. https://doi.org/10.1080/17421772.2014.904615

Mankiw, N. G. (2019). Macroeconomics (10th ed.). Macmillan Learning. Retrieved from https://books.google.co.id/books?id=Ek6SugEACA A]

Nopembereni, E. D., Sugiyanto, S., Sukesi, K., \& Yuliati, Y. (2019). Local wisdom in shifting cultivation management of Dayak Ngaju Community, Central Kalimantan. Journal of Socioeconomics and Development, 2(1), 38-44. https://doi.org/10.31328/jsed.v2i1.939

Nyoman, N., Sudewi, A., \& Wirathi, I. G. A. P. (2013). Pengaruh desentralisasi fiskal dan pertumbuhan ekonomi terhadap kemiskinan Provinsi Bali. E-Jurnal EP Unud, 2(3), 135-141. Retrieved from https://ojs.unud.ac.id/index.php/eep/article/view/ $4434 / 3725$

Qiao, B., Martinez-Vazquez, J., \& Xu, Y. (2008). The tradeoff between growth and equity in decentralization policy: China's experience. Journal of Development Economics, 86(1), 112128.

https://doi.org/10.1016/j.jdeveco.2007.05.002

Salqaura, S. S., Mulyo, J. H., \& Darwanto, D. H. (2019). The influence of fiscal policy on agriculture sector in Java island. Agro Ekonomi, 29(2), 173-184. https://doi.org/10.22146/ae.35044

Siburian, M. E. (2020). Fiscal decentralization and regional income inequality: evidence from Indonesia. Applied Economics Letters, 27(17), 1383-1386. https://doi.org/10.1080/13504851.2019.1683139

Soejoto, A., Fitrayati, D., Rachmawati, L., \& Sholikhah, A. (2016). Typology of regional economic development pattern. International Journal of Applied Business and Economic Research, 14(13), 9493-9505. Retrieved from https://serialsjournals.com/abstract/27493_46ady_soejoto.pdf

Sukirno, S. (2002). Pengantar Teori Mikroekonomi. Jakarta: RajaGrafindo Persada. Retrieved from https://books.google.co.id/books?id=kHTAtgAACA AJ

Suwardi, A. (2011). Pengeluaran pemerintah daerah, produktivitas pertanian, dan kemiskinan di Indonesia. Jurnal Ekonomi dan Pembangunan Indonesia, 12(1), 39-55. https://doi.org/10.21002/jepi.v12i1.287 
Syari, D. D., Syamsurijal, S., \& Robiani, B. (2017). The effect of fiscal decentralization to gross domestic regional product of district/city in South Sumatra Province. Sriwijaya Int. Journal of Dynamic Economics and Business, 1(2), 181-202. https://doi.org/10.29259/sijdeb.v1i2.181-202

Todaro, M. P., \& Smith, S. C. (2015). Economic Development (12th ed.). Pearson. Retrieved from
https://books.google.co.id/books?id=sMKmngEAC AAJ

Wardie, J., \& Sintha, T. Y. E. (2018). The sustainability level of the rice farming in the peatland at the Kapuas Regency, Central Kalimantan. Journal of Socioeconomics and Development, $1(1)$, $38-42$. 